\title{
Anna Owczarczyk
}

Siedlce University of Natural Sciences and Humanities (Poland)

ORCID: 0000-0003-1363-2296

e-mail: anna.owczarczyk@uph.edu.pl

\section{Social Policy Programme "The Family 500+" - Assumptions, Results, and Costs of Functioning: Is It Worth?}

\begin{abstract}
The unfavorable demographic situation and the falling number of births resulted in an increased interest among Polish politicians in introducing tools to social policy that would reverse this negative trend. Implemented to social policy by Prawo i Sprawiedliwość Party in 2016, the "Family 500+" benefit has become such a tool. According to the government's intention, this financial aid for families with children aims to reverse the decline in the number of births observed for many years and reduce the scale of poverty among families with the most complex financial situation. After several years of the "Family 500+" Programme in force, it is difficult to clearly define whether the goals were achieved and whether the expenses for financing the programme were adequate to the results. The aim of the article is an attempt at the assessment of the functioning of the Family 500+ Programme. Both the statutory assumptions of the programme, the costs of its functioning, and its results so far were analyzed. The central part of the analysis covered the period 2016-2019.
\end{abstract}

Keywords: 500+ Programme, poverty, social policy, pro-natal policy

\section{Introduction}

The evolution of the modern family linked to dynamic changes in social, economic, and political life puts the state an obligation to increase assistance for families. According to Malinowski, the strategic objective of the family policy should be improving the conditions for establishing and functioning of families, increasing the level of births, as well as mitigating the impact of family poverty and reconciling the needs related to professional, material aspirations and the needs of children (Malinowski, 2010, pp. 79-101). 
One of the tools to support Polish families and implement social policy is the Family $500+$ Programme 1 initiated in 2016. In the opinion of the programme's authors, it is proof of solidarity with Polish families, the sign of care for Polish children, and an attempt at overcoming a demographic crisis. It constitutes an extension of the existing system supporting families, and it functions independently of other forms of support in use hitherto, such as social assistance or family benefits. The introduction of the $500+$ benefit has increased the total value of existing financial support for families by about 140\% (Ministry of Family and Social Policy, Twitter, March 28, 2019).

The aim of the article is an attempt at the assessment of the functioning of the 500+ Programme to date. Both the statutory assumptions of the programme, the costs of its functioning, and its results so far were analyzed. The analysis covered years 2016-2019, which is when the 500+ Programme was functioning and the previous years due to comparing the impact of the 500+. The research methods applied for this article include foremost the analysis of publications regarding the 500+ Programme (benefit) and the secondary analysis of reports and studies.

\section{The Characteristics and Statutory Assumptions of the 500+ Programme as a Tool Implementing Social Policy}

The main instrument of social policy concerning families is the so-called family benefits regulated in the Act of 28 November 2003 on family benefits (Journal of Laws 2003 no. 228 item 2255 as further amended). They serve many functions, including income compensating, redistributive, egalitarian, and stimulating functions (Auleytner, Głąbicka, 2000,p. 16). Article 2 of the Act enumerates the following benefits:

- family allowance and supplements to the family allowance,

- carer's benefits: a care allowance, a special carer's allowance, and a care benefit

- a grant paid out by the municipality,

1 Others include: the so-called "becikowe" (a maternity grant) - a single-payment grant on the occasion of child birth, the Good Start is PLN 300 of a single-payment support for all pupils starting their school year, the Toddler+ Programme - supports the development of institutions caring for children up to 3 years of age, beneficiaries may obtain co-funding to create and operate care places, the Mum 4+ Programme - is a parental supplementary benefit aimed at persons who, so as to raise at least four children, could not take up work or resigned from it, the Pension + is a single-payment benefit for pensioners in the amount of the minimum pension, the Meal at School and at Home - provides support for communes so as to offer assistance in the form of meals, a benefit in cash in the form of a purpose benefit to buy a meal or food and a benefit in kind in the form of food products for children, youth and adults, the Ending Homelessness Programme - aimed at inspiring and supporting activities directed to counteracting and solving the problem of homelessness, the Travel and Work Programme - the programme combines a holiday and getting to know or extending the knowledge of the language and culture of the visited country with a simultaneous opportunity to take up gainful employment. 
- a single-payment grant on the occasion of childbirth,

- parental benefits - introduced on January 1,2016 (section 3a of the Act), replacing the maternity benefit for persons who are not entitled to it at the Social Security Institution (ZUS) or Agricultural Social Security Fund (KRUS). It is granted in the amount of PLN 1,000 for 52 weeks from childbirth.

Apart from being entitled to the benefits mentioned above, families with children in a difficult financial position may also apply for other forms of assistance from social care such as schooling allowances or subsidies to meals in school canteens, which constitute an element of the social policy (Podgórska-Rykała, Zasuń, 2018).

On February 11,2016, the Act on state aid in raising children (Journal of Laws 2016 item 195 as further amended) was adopted. It aims to grant financial assistance to families raising children. Under this Act, in April 2016, child support of PLN 500 (the so-called 500+) was introduced, which is now regarded the most expensive instrument of the family policy of the III Republic of Poland (Gromada, 2017,pp. 1-26). The support is transferred to parents, legal guardians, or actual guardians, irrespective of the family income, for each child who has not turned 18 years of age. The programme also covers children from family-type children's homes, educational care facilities, and children raised in foster families. The programme does not provide the maximum income criterion, which would set the level of family income. If exceeded, the support would be withdrawn partly or entirely.

The Act specifies both the conditions for entitlement for the support as well as regulations for granting it. In the introduction, it is clarified that foremost the support is due to Polish citizens and foreigners, on condition that they meet respective requirements and reside in the territory of the Republic of Poland. By mid-2019 key criteria entitling for the support were the number of children in the family and income per family member ${ }^{2}$. In this period, the support was due to each second and further child in the family. Whereas for families living on the lowest income - net income per person of not more than PLN 800 (or PLN 1,200 when there was a disabled child) was also due to the first child. Unfortunately, the income criterion - PLN 800 - adversely affected the most impoverished families, in which a single parent raising one child and earning the minimum wage was not entitled to the support as their income per family member was PLN 886 net (the minimum wage in 2018: PLN 1,771). In December 2018, the programme covered 3.74 million children (61\% of children up to 18 years of age in Poland) from more than 2.45 million families (www.mpips.gov.pl, March 28, 2019).

As a result of amendments introduced on July 1,2019, the scope of the support was extended, and it was dedicated to all children up to 18 years of age irrespective of the income received by the family. Consequently, 6.8 million children are now entitled to the support (MPIPS, 2020).

2 In 2015 during the election campaign the politicians of the Law and Justice political party emphasized that it would be the support for all Polish families irrespective of their financial situation. 
Family benefits, methodologically similar to the $500+$ benefit function in many European states, both those who belong to the "old" Union (e.g., Germany, Belgium, Holland, Sweden) and those that joined the EU within the last years (e.g., Hungary, Romania, Latvia, Slovakia) (Ministerstwo Rodziny, Pracy i Polityki Społecznej, 2019). Some states link the benefit to the number of children, their age, and family income situation. Moreover, many states also apply other tools of family-centered policy, e.g., the so-called "family quotient" (in France), preferential tax treatment (e.g., in Belgium, Estonia, France, Spain), deduction of expenses on child care, education, etc. (e.g., in France) (PWC, 2016).

Table 1. Sample amounts of child support (the equivalent of 500+) in selected EU states (regardless of criteria, EUR)

\begin{tabular}{ll}
\hline State & Support amount \\
\hline Austria & $114-165$ \\
\hline Belgium & $92-259$ \\
\hline Finland & $94-172$ \\
\hline Germany & $194-225$ \\
\hline Latvia & $11.38-50.07$ \\
\hline Sweden & $15-179$ \\
\hline Hungary & $37-52$ \\
\hline Poland & 115 \\
\hline
\end{tabular}

Source: https://www.gov.pl/documents/1048151/1060973/OSR500plus.pdf/6b0b8c66-21c0-e867-509fddf7bdb4380a (8.03.2020)

As a result of the implementation of the 500+ Programme, Poland is at the top of the states offering the highest family support. The average amount of EU member states aid in the scope of child relief and family benefits was about PLN 10,178 annually in 2016. Whereas in Poland, it was PLN 8,225. Compared to the average pay, Poland is in the fourth position among the $28 \mathrm{EU}$ member states (PWC, 2016).

The support is funded with public funds out of the state budget, and it is transferred as a designated subsidy to municipalities. To serve the 500+ Programme, municipalities were entitled to $1.5 \%$ of the state budget subsidy received towards child support. In 2019 the ratio was lowered to $1.2 \%$, and starting from January 1,2020, a further decrease to $0.85 \%$ has been planned (Kubicka-Żach, 2019). The support procedure is carried out by the municipality executive body appropriate for the place of residence of the person applying for the support. In the case of persons who are Polish citizens but reside abroad, the applications are considered by the governor (previously, it was within the competence of the marshal of the voivodship).

Analyzing the legislative process and the justification for the Act on state aid in raising children, we should draw attention to faults that question the correct formulation of the objectives of the public policy. These objectives should be clearly stated, articulate, supported by reliable research, and measurable (Gromada, 2017). In the justification to the Act on 
state aid in raising children (Journal of Laws 2016 item 195 as further amended) (in the Assessment of the Results of the Regulation section), two main objectives the 500+ support is aimed at were indicated. These are (Druk Sejmowy nr 216, 2020):

1. counteracting demographic decline,

2. a decline in poverty.

Unfortunately, as A. Gromada (2017) points out, both objectives are not transparent enough, and what is more, they may be interpreted freely in the context of achieving them. In the case of verification of the achievement of the first objective, we may apply the markers of the population growth or/and rise in the fertility rate. Indicating which markers shall be applied is crucial at this stage of legislation as the mentioned markers worked in opposite directions. As for the second objective, A. Gromada questions the reliability of research and the lack of clarification as to what type of poverty the legislator had in mind (extreme, relative, or statutory). Regardless of the type of poverty, in 2005-2014, the level of each of them declined, and in 2013-2014 (that is just before and during the work on the bill), we recorded the stabilization of the extreme poverty (at 7.4\%) and the relative one (at 16.2\%) as well as a decline of the statutory poverty from $12.8 \%$ to $12.2 \%$.

In turn, in the presentation of the draft bill in the Sejm (the Lower Chamber of the Polish Parliament), the possible impact of the support on poverty was emphasized as follows: "owing to the implementation of the family support, poverty may drop by three percentage points, and the risk of poverty among children up to 17 years old will decrease from $23.3 \%$ to $11 \%$ " (Rafalska, 2016). It was also stated that the support had three main equivalent objectives (Szarfenberg, January 16, 2020):

1. increasing the fertility rate,

2. investment in the human capital,

3. reduction in destituteness among the youngest Poles.

Unfortunately, we may notice some methodological flaws. Firstly, financial support for families may affect the quality of family life, improvement of the health of family members, or school achievements (Aizer et al., 2016, pp. 935-971); however, there is no study which would prove the statement that additional financial resources affect the growth of fertility rate (Dziwosz, 2017,pp.210-211). Secondly, the wording "investment in the human capital" is so inclusive that every action resulting in the increased consumption or savings may be treated as a political success of the $500+$ Programme (Gromada, 2018). In turn, the objective, which is the decline in destituteness among children, should be put on a par with the decline in poverty among children. Thus, again, a question arises what type of poverty the legislator had in mind: extreme, relative or statutory.

Summing up, legislative assumptions of the Family 500+ Programme show considerable methodological flaws, namely incorrectly formulated objectives. Thus, in the future, they may pose considerable difficulties in interpreting the results, effectiveness, and profitability of the implementation of this tool. It may be assumed that such a situation will benefit those who initiated the 500+ Programme as the dilution of results will make it possible 
to select the most favorable version, and the lack of transparency will help cover up potential failures.

\section{Results of Functioning of the 500+ Programme Hitherto - An Attempted Evaluation}

The Family 500+ Programme stirred and still does stir extreme emotions. On the one hand, as an election slogan "PLN 500 for each child (...)" it was well-received by a large part of the society, as it was bringing hope for the improved financial situation of families (setting aside the question of what this sum will be spent on). On the other hand, it harbored reservations from economists due to the programme assumptions and the scale of expenditure out of the state budget.

During the first nine months of the programme implementation, i.e., from April till the end of 2016, the number of children covered with this support was 3.8 million, in 2017: 3.79 million, in 2018: 3.6 million and in 2019, after the introduction of the extended version of the programme, it is estimated that 6.8 million children are entitled to the support (MP, 2019)

Below we discuss selected results of the 500+ Programme, which may be observed after its four-year-long functioning.

The 500+ support is considered one of the most expensive support programmes for Polish families in recent years. Starting from 2017, the expenditures on the programme are recorded in "855 - Family", the newly-established section of the budget classification. Apart from the 500+ support, this section covers: expenditure on supporting families (including expenditure on family assistants and support families as well as day support facilities) under the provisions of the Act of 9 June 2011 on family and foster care (Journal of Laws 2016 item 575) and expenditures arising from the Act of 5 December 2014 on the Large Family Card (Journal of Laws 2016 item 785, expenditure incurred on, e.g., creation and functioning of crèches, kid clubs, adoption centers, and care and education facilities, expenditure incurred on foster families and daycare providers (which were moved from sections: " 852 - Social assistance" and "853 - Other tasks regarding social policy"), social security payments for persons on childcare leave, for persons drawing maternity allowance, for persons employed as childminders and for persons having personal care of children (moved from section "753 - Compulsory social security"). Total expenditure on the payment of $500+$ benefit amounted to (GUS, 2016,2017,2018): in 2016: PLN 17,080.9 million (04-12), in 2017: PLN 23,171.3 million, in 2018: PLN 22,169.9 million. In 2017, there was an increase in the paid out amount of 35\% compared to the previous year, which is justified as in 2016 the programme covered only nine months. In turn, in 2018, there was a 4.3\% decrease compared to 2017 and, at the same time, a drop in the number of children entitled to the support. The amount transferred to Polish families from the beginning of the programme until the end of February 2019 is PLN 67 million (NIK, 2019). 
The $500+$ benefit as financial support for families is financed as a designated subsidy from the state budget. The cost of servicing the $500+$ Programme was determined as a percentage of the amount of the subsidy aimed at financing the programme. In 2016, it was $2 \%$, from 2017 to 2018 - 1.5\%, in 2019 - 1.5\% (January-June), 1.2\% (July-December), whereas in 2020 it is planned at $0.85 \%$. The reduction of the cost of servicing may result from the fact that part of the duties connected with formalities relating to the application for $500+$ benefit was assumed by commercial banks enabling their clients to file an electronic application to an appropriate Social Assistance Centre free of charge, which limits the number of persons who need to be employed to service the programme. Moreover, further years of functioning of the 500+ Programme have stopped generating high costs such as trainings for employees paying out the benefit and spending on intense promotion and advertising of the programme. Moreover, we should consider the abolition of the income threshold and extending the benefit to the first child as such a change also results in decreasing the costs of servicing the programme.

The implementation of the Family 500+ Programme starting from its introduction in 2016 costs the Polish state nearly PLN 22 billion a year, which is $1.5 \%$ of the GDP, and according to the Supreme Audit Office 500+ is the main reason for the increase of expenditure on social transfers from 14.3\% GDP in 2015 to 15.3\% GDP assumed by the government in 2020. Consequently, despite limiting spending on other purposes, the total spend may increase up to $42.8 \%$ GDP in 2020 . Hence, with an increase in the tax burden on the economy, taxes will probably rise from 33.2\% to 37.5\% GDP in 2020 (NIK, 2019). The outlook for public finance shows that the $500+$ benefit is a heavy burden on the state budget, and every citizen will feel the consequences.

Starting from March 2020, in light of the 500+ benefits and the growing budget expenditures, the legislator wants to introduce changes concerning implementing new services supporting large families (MW-G, 2020). Thus, this will not be changes adjusting the current benefit with the inflation rate but completely new initiatives.

Another question raised in connection with the finances of the 500+ Programme is its promotional costs which in 2017 reached nearly PLN 3 million (MP, 2019). However, comparing this sum to the annual global amount assigned to the payment of the benefit is just a tiny fraction.

\section{Results of the Implementation of the 500+ Programme}

In line with the assumptions of the legislator, the 500+ benefit was aimed at counteracting demographic decline and reducing poverty (leaving aside doubts mentioned afore regarding the formulation of objectives). As the research conducted by the IBS, CenEA, GRAPE, Warsaw School of Economics, and Warsaw University shows, the implications of the programme for the labor market, the cohesion of the family policy or public finance are not satisfactory (Magda et al., 2019). 
First of all, the 500+ Programme was supposed to contribute to the demographic growth and an increased number of births. Actually, in the first two years of the programme functioning, a natural increase was recorded, which was interpreted as a success by the programme supporters. However, as statistical data show in 2016-2019, i.e., when the 500+ Programme functioned, only in 2016 and 2017 the number of births rose. In the remaining years, there was no such a trend. In 2016 nearly 13,000 more children were born than in 2015, and in 2017 about 20,000 more. In the following years, 2018 and 2019 (Szymański, 2020), there is a decrease in births. In 2018, there was a contraction of 14,000 in childbirths compared to 2017 and 2019 - a contraction of 13,000. Chart 1 below shows the demographic situation in Poland in the last decade (2009-2019).

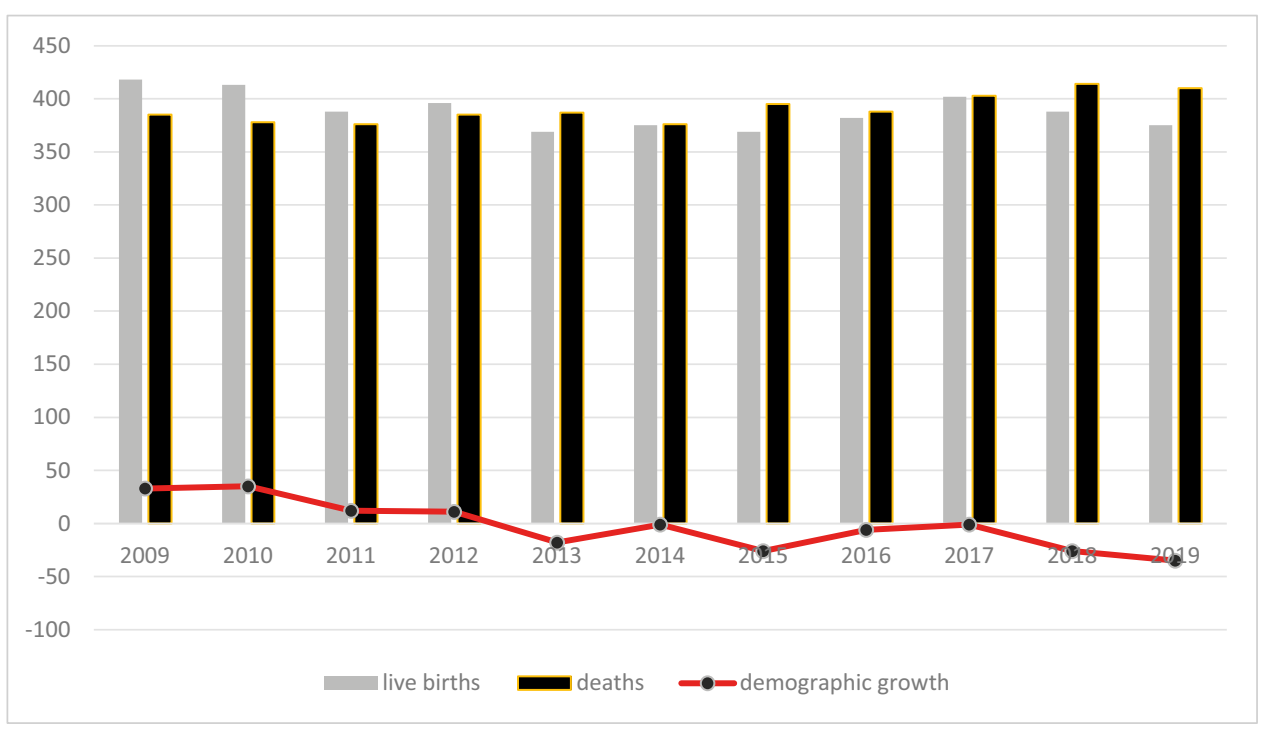

Chart 1. Live births, deaths, demographic growth (PLN thousand, 2009-2019) Source: Own elaboration based on GUS statistical data

Making a brief analysis of the statistical data presented in the chart, we notice that there is a downward demographic trend in the analyzed period. When the 500+ Programme has been functioning, we could see that only in the first two years (2016 and 2017) there was both an increase in the number of births and a positive trend in demographic growth. As researchers point out, however, the results of these first two years were not the effect of the implementation of the 500+ Programme. It may be the consequence that actions were introduced in the previous years, which affected procreation decisions. We should mention here the following:

- introduction in 2011 of the Act on the care of children under three years of age and a new government programme "Toddler" which facilitated the development 
of care and education services for the youngest children and made these services more accessible,

- extending the leave connected with childcare (2013),

- introducing a parental benefit constituting a type of maternity benefit for nonworking persons and those insured at the Agricultural Social Security Fund,

- the amount of and the regulations for granting tax relieves for children were amended (2015).

Some of these changes increased the sense of stability in persons planning to have children, but some had the opposite effect. Considering all changes introduced in the last decade, it is impossible to isolate the effects of one particular solution, such as the 500+ benefit on fertility decisions. Analyzing the experiences of other countries and the results of studies devoted to factors affecting childbirth decisions, in no manner may we attribute fertility to social benefits: a financial situation is just one of the premises for a decision regarding (another) child (Magda et al., 2019).

Moreover, positive changes in 2016 and 2017 may be explained with a favorable situation on the labor market (increased chances of finding a job), an increase in the minimum wage (which has been rising considerably since 2014), and at the same time of the average wage.

The second objective of the 500+ Programme was the reduction of poverty. Also, in this case, similarly to the increase in births, poverty rates decreased in 2016 and 2017, whereas, in 2018, they increased.

As the analysis of StatisticsPoland indicates, in 2016, a considerable drop in poverty was reported regarding extreme poverty and relative poverty. In 2016, nearly $5 \%$ of persons lived in extreme poverty (whereas in 2015 - 7\%), and in the relative poverty - slightly below $14 \%$ of persons (compared to almost $16 \%$ in 2015). A considerable drop in poverty was observed primarily among such groups as large families, households including disabled persons, persons living in villages and towns with a population of under 20,000. Despite an improvement in the situation, these groups were still under the highest threat of poverty. In 2016, a significant improvement in households with children under 18 years of age was observed. The effect was a visible drop in extreme poverty among children aged 0-17 (from 9\% in 2015 to slightly less than 6\% in 2016) (GUS, 2016). In 2017 a further drop in the economic poverty estimated based on the study of household budgets was recorded. A significant improvement was primarily observed among families with children, persons with lower education, and the rural population. As analysts point out, the factors which to the largest extent contributed to the improvement of the financial situation of households and a drop in extreme and relative poverty in 2016 and 2017 were: an increase in wages, a decrease in unemployment, and in the case of families with children the Family 500+ care benefit (GUS, 2018).

Unfortunately, this favorable climate was subdued in 2018 when an increase in the percentage of poor persons among households with children under 18 years of age was 
recorded. The poverty rate increased the most in multi-child households (with at least three children) and households with one child. Consequently, the extent of poverty among children and youth under 18 years of age increased from nearly 5\% in 2017 to $6 \%$ in 2018 . Poverty in households living primarily on social security benefits (other than pensions) increased considerably. Unfavorable changes in the scale of extreme poverty in 2018 referred to a larger extent to the rural population rather than the urban one. In rural areas, the extreme poverty rate increased by about $2 \%$. There was also an increase in cities, but it was only slight, as it did not exceed $1 \%$ (GUS, 2019).

Although according to Statistics Poland, poverty increased, the government claims that the situation of families improved. As proof of this improvement, it states that in 2018 mainly owing to the 500+ Programme - the number of families with children relying on social security benefits dropped by about 163,000 compared to 2015 (Kamińska, 2019).

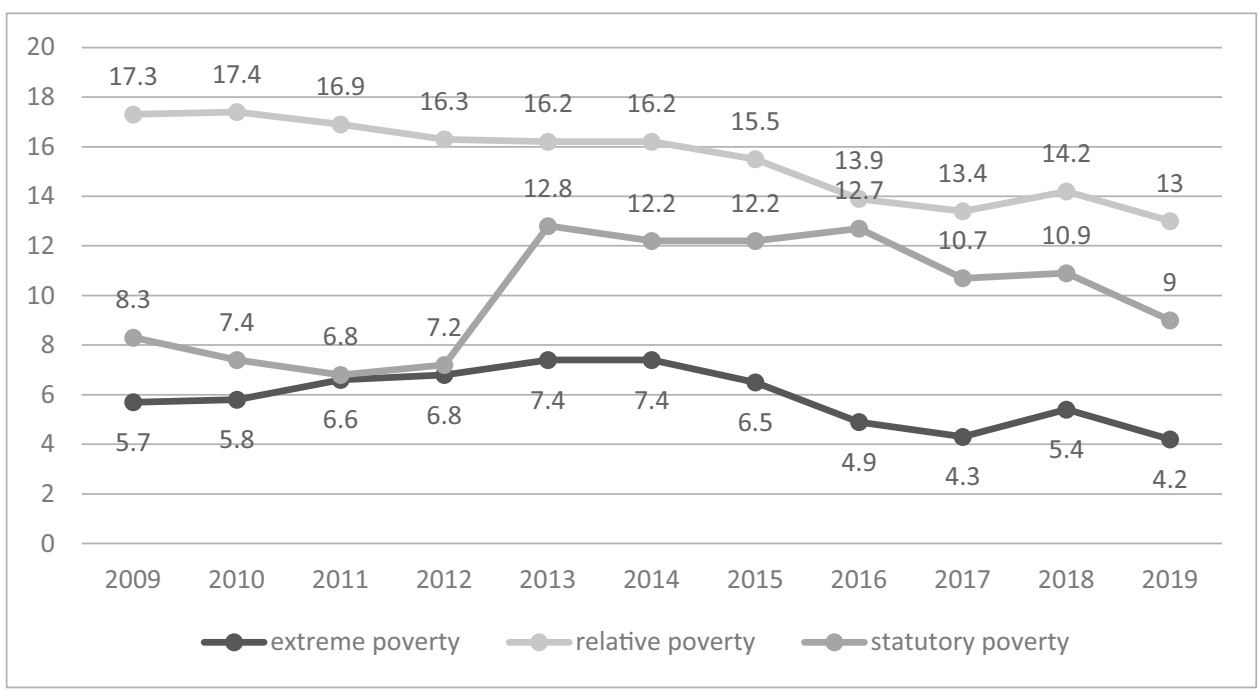

Chart 2. Poverty rates in Poland (\%, 2008-2019)

Source: Own elaboration based on GUS statistical data

2018 saw an end to the downward trend in the scale of economic poverty estimated based on household expenditure. Compared to 2017, there was a rise in extreme poverty (from about $4 \%$ of persons to about $5 \%$ of persons) and the scale of relative poverty (from about $13 \%$ of persons to about $14 \%$ of persons).

At this point, we should ask about poverty rates for 2020 . They may change in the opposite direction for reasons such as extending the 500+ Programme to every child in the family without applying an income criterion. It is worth taking into account the pandemic situation, which influences state economics in a significant way. 
A quite widely commented in the media effect of the implementation of the 500+ Programme which was noticed a year after the implementation was a decrease in the number of economically active women, that is those, who are in work or are willing to take up a job and are looking for it. The limitation of economic activity of women might have resulted from numerous reasons (however, the $500+$ benefit was put in the center of attention), which may include: lower average wages of women in Poland as compared to men (by about 18\%), two-fold larger input of work in the household, especially in childcare (Magda et al., 2019). Moreover, in low-income families, the threshold entitling to draw the 500+ benefit for the first child was also a demotivating factor and discouraged from economic activity. Some persons whose income just minimally exceeded that level (PLN 800) could have resigned from work to obtain the benefit for the first child. It is estimated that during the year from the start of the first payments under the 500+ Programme (i.e., since mid-2017), about 91,000-103,000 women having one child or two children withdrew from the labor market, resigning from employment, or gave up looking for it (Magda, Kiełczewska, 2018, pp. 7-9).

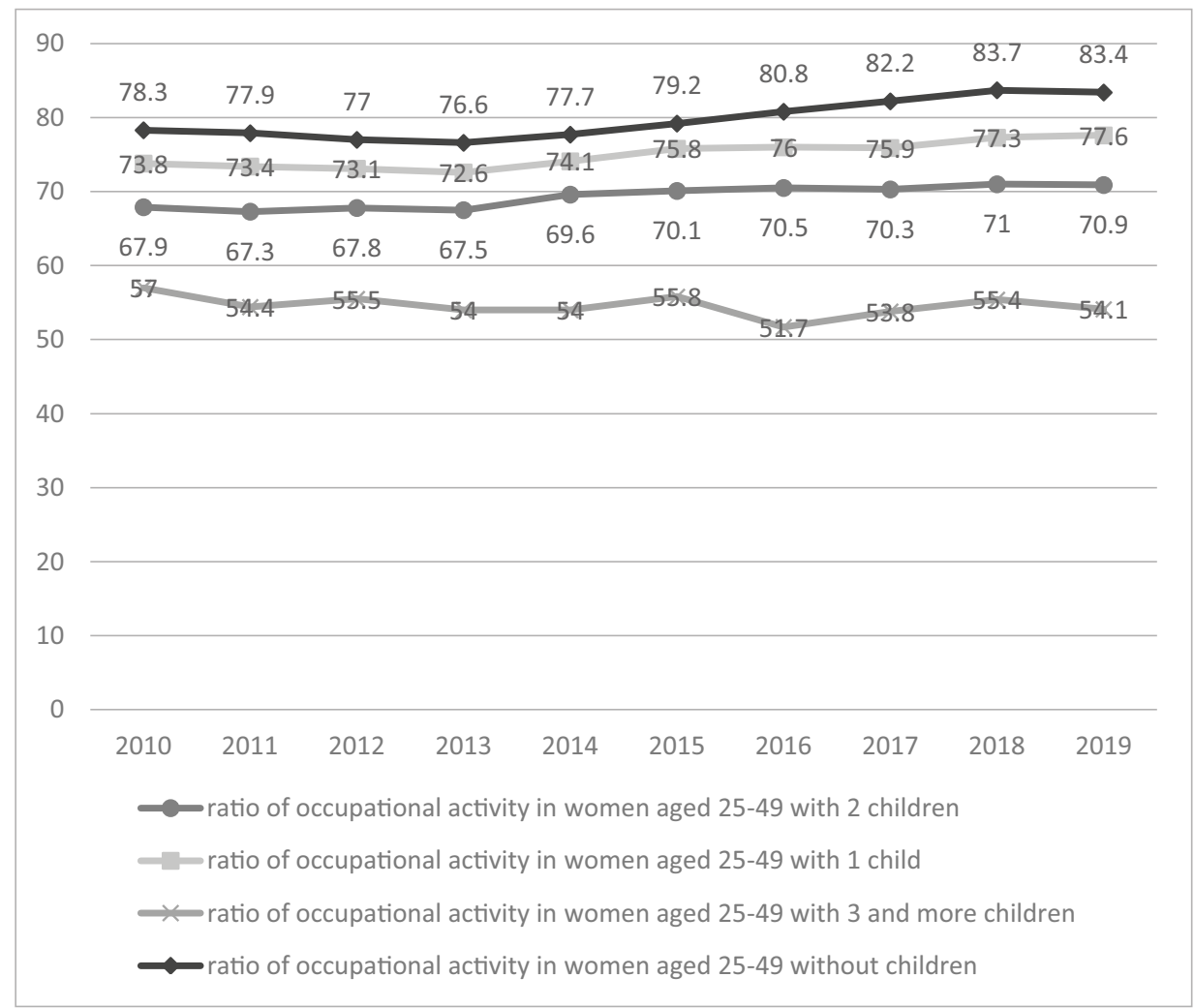

Chart 3. The ratio of occupational activity in women aged 25-49 (\%, breakdown by the number of children) Source: own elaboration based on Badania Aktywności Zawodowej Ludności (The Labor Force Survey) of Statistics Poland. 
Analyzing statistical data from Statistics Poland, the total ratio of women's occupational activity did not show significant fluctuations in 2010-2018. However, we may note some fluctuations in their occupational activity for the ratio for women aged 25-49 starting from 2016. Analyzing the data presented in chart 1, we may note that women's occupational activity in the studied age group (irrespective of the number of children) has successively been increasing since 2013. The highest amplitude of fluctuations may be seen in women having three or more children. In this group of respondents, there was a significant reversal of the trend in 2016, and in 2017 the increase was only slight. This result is attributed to implementing the 500+ Programme and the payment of the first benefits as was already mentioned. However, attention should be given to the following years when the benefits were paid out, starting from 2018. We may see a visible improvement in the women's occupational activity. According to Statistics Poland surveys, women's occupational activity in families having two children is on the increase (the ratio of women's occupational activity is: 2017 - 70.3\%, $2018-71 \%, 2019$ /Q3/ - 74.7\%, also in families having three or more children 2017 - 53.8\%, 2018 - 55.4\%, 2019/Q3/ - 56.2 (GUS, 2019). These are pretty sensational results, as so far, it has been widely believed that $500+$ contributes to a decline in women's interest in work. The Central Statistical Office explains the changes in the trend based on the survey $(\underline{M M}, 2020)$ and concludes that owing to the $500+$ benefits, parents can provide care for children, and more Poles can "afford" work. This conclusion is quite controversial because following this line of reasoning, if the 500+ Programme had not been introduced, more and more women would not be interested in taking up and looking for a job.

In the studies conducted so far, it is difficult to find analyses covering years 2016-2019 that would indicate the extent to which children's health and susceptibility to diseases affect the economic inactivity of women, especially in families with many children. It is known that frequent illnesses in children aged 1-7 result in frequent sick leave by parents, often mothers (especially in large families), which reduces their credibility and availability in the employer's eyes. Thus, they may decide to temporarily leave the job to care for children and return to work after that time.

Another issue in the 500+ benefit is where the programme's beneficiaries allocate the money they receive. According to studies carried out systematically in 2016-2018, parents used additional funds to increase consumption and rarely distinguished these funds as "children's money". According to Rudke (2017), the highest percentage of the households surveyed allocated funds from the programme to cater to basic needs. $51 \%$ of respondents declared that they bought food and clothes. Expenditure on education and training for children also increased ( $45 \%$ of respondents declared this goal). $20 \%$ of respondents financed entertainment expenses from the 500+ Programme, and nearly $14 \%$ of respondents declared an increase in savings. In 2019, when the legislator decided to extend the 500+ Programme to the first child, the Chamber of Fund and Asset Management researched potential beneficiaries, asking what they intended to spend additional funds on. 30\% of 
respondents declared support for the education of their children, i.e., financing tutoring or purchasing school supplies. $27 \%$ of respondents declared spending on the general needs of a child. $15 \%$ of parents would save money for the future of their child. These responses were followed by respondents stating that they were planning to use the funds from 500+ Programme to finance current expenses (9\%), entertainment (8\%), food supplies (7\%), and vacations (6\%) (IZFiA, 2019).

Having analyzed the survey results, it should be stated that the money contributing to the budgets of big families from the 500+ Programme certainly facilitated family's access to the market offer, increased consumption and resulted in "loosening of the financial discipline of the household budget" (analizy.pl, 2019); thus, it increased the financial capacity of household budgets.

\section{Conclusions and Recommendations}

The 500+ Programme was launched in April 2016, and it significantly increased public expenditure on social benefits (from $1.4 \%$ to $2.7 \%$ GDP). In July 2019, changes were introduced to the programme, and more precisely, income selection was abolished for the first child. That year, the programme covered 6.8 million children in Poland.

When analyzing the functioning of the 500+ Programme so far, it can be concluded that it has its advantages, but it is also not without drawbacks.

The advantages include:

1. a simplified distribution system with low administrative costs: the Family 500+ Programme can be considered as one of the cheapest to operate. It is because some obligations related to the procedures have been taken over by the private sector, e.g., banks, which enable the completion of the benefit application forms and refer it to the competent commune office or social welfare center.

2. no controversy regarding the idea of support and egalitarianism: joining the programme is a voluntary decision of a citizen, and the abolition of the income threshold in 2019 does not divide eligible people into those better and worse-off.

3. a very nicely wrapped political product that contains catchy slogans and meets the expectations of society.

The disadvantages include undoubtedly:

1. no precise indicators for evaluating the programme or the determination of the level of expected results. The goals assumed by the legislator were outlined very generally, and in the declarations of politicians from the ruling party, they changed over time. There were also no specific measures that would make it possible to measure the degree of achievement of the assumed goals;

2. depreciation of the amount of the benefit in a long-term perspective; otherwise, it will generate increased expenditure from the state budget; 
3. low controllability: the $500+$ Programme is a privilege for the majority of the society, and if there are changes in the economic environment changes or negative economic trends, the programme may prove very difficult to "close".

Moreover, in conclusion:

1. the conducted research does not indicate clearly that the $500+$ benefit resulted in a significant decrease in poverty. The decline in poverty turned out to be short-lived and lower than forecast, and, above all, it could be achieved at a much lower cost. However, it can be seen that owing to the Family 500+ Programme, the quality of life of many families has improved;

2. the payment of the 500+ benefit has not affected the birth rate, and the two-year "peak" in 2016 and 2017 was too short to be considered a result of the introduction of the 500+ Programme. It should be noted that the increase in birth rates is influenced by many factors, such as the economic situation, availability and wage attractiveness of jobs, or even the system of providing care for children aged 1-6 (number of nurseries and kindergartens);

3. in the early years of introducing the Family $500+$ Programme, there was a decline in the professional activity of women, which many analysts associated with receiving benefits. The studies of the subsequent years, 2017-2019, show a reverse trend, which undermines previous conclusions and assessments;

4. the funds from the 500+ programme were not always allocated to the needs related to the children's development and upbringing. They contributed to all household expenses instead;

5. removing the income barrier and extending the programme to the first child generates more and more expenditure from the state budget while at the same time slightly increasing the purchasing power of the programme beneficiaries. Rising inflation (in December 2019 - 3.4\%) depreciates the benefit from PLN 500 / month in 2016 to PLN 270 / month in 2019.

Recommendations:

1. The objectives of the 500+ Programme should be reformulated, and measures need to be devised that will allow the transparent assessment of the impact of the 500+ benefit on the economic and social situation of the country.

2. It is worth considering new services, not necessarily another co-financing, aimed at supporting families. These options may include increasing the number of public nurseries and kindergartens or establishing on-site child care facilities at workplaces. 


\section{References:}

Aizer, A., Eli, S., Ferrie, and J., Lleras-Muney, A. (2016). The long-run impact of cash transfers to poor families. The American Economic Review, 106(4), 935-971.

Analizy.pl. (2019, September 18). 500+ na pierwsze dziecko. https://www.analizy.pl/tylko-unas/24382/500-na-pierwsze-dziecko-na-co-rodzice-przeznaczaja-uzyskane-srodki.

Auleytner, J., \& Głąbicka, K. (2000). Polityka społeczna pomiędzy opiekuńczościa a pomocniczościa. Warszawa: WSP TWP.

Druk Sejmowy nr 216 Rządowy projekt ustawy o pomocy państwa w wychowywaniu dzieci. Retreived from: http://www.sejm.gov.pl/Sejm8.nsf/druk.xsp?nr=216.

Dziwosz, E. (2017). Minusy programu 500 plus. Zeszyty Naukowe Politechniki Ślaskiej, Seria: Organizacja i Zarzadzanie, 104.

Gromada,A.(2017). Rodzina 500+ jako polityka publiczna. Krytyka polityczna. https://krytykapolityczna. pl/file/2016/02/gromada_rodzina_500.pdf.

Gromada, A. (2018). Czemu służy program rodzina 500 plus? Analiza celów polityki publicznej i polityki partyjnej. Ruch Prawniczy, Ekonomiczny i Socjologiczny, 3.

GUS. (2019) (2018) (2017). Dzieci i rodzina 2016, 2017, 2018. https://stat.gov.pl/obszary-tematyczne/ dzieci-i-rodzina/.

GUS. (2019).Zasięg ubóstwa ekonomicznego w Polsce w 2018 r. https://stat.gov.pl/obszary-tematyczne/ warunki-zycia/ubostwo-pomoc-spoleczna/zasieg-ubostwa-ekonomicznego-w-polsce-w-2018roku, 14,6.html,14,6.html.

GUS. (2017).Zasięg ubóstwa ekonomicznego w Polsce w 2016 r. https://stat.gov.pl/obszary-tematyczne/ warunki-zycia/ubostwo-pomoc-spoleczna/zasieg-ubostwa-ekonomicznego-w-polsce-w-2016-r-,14,4. html.

GUS. (2018).Zasięg ubóstwa ekonomicznego w Polsce w 2017 r. https://stat.gov.pl/obszary-tematyczne/ warunki-zycia/ubostwo-pomoc-spoleczna/zasieg-ubostwa-ekonomicznego-w-polsce-w-2017-r-,14,5. html.

GUS. (2020). Aktywność ekonomiczna ludności Polski III kwartał 2019 roku. https://stat.gov.pl/ obszary-tematyczne/rynek-pracy/pracujacy-bezrobotni-bierni-zawodowo-wg-bael/aktywnoscekonomiczna-ludnosci-polski-iii-kwartal-2019-roku,4,35.html.

IZFIA. (2019). “500 plus” Raport. https://www.izfa.pl/raporty\#pozostale-raporty.

Kamińska, A. (2019, July 30). Ubóstwo w Polsce. Najnowszy raport GUS: Mimo socjalnych programów PiS w Polsce w 2018 r. wzrosło ubóstwo. https://plus.dziennikbaltycki.pl/ubostwo-w-polscenajnowszy-raport-gus-mimo-socjalnych-programow-pis-w-polsce-w-2018-r-wzroslo-ubostwo/ar/ c1-14311721.

Kris/ToL. (2018, February 2). Miliony złotych na 500 plus. Rząd podał, ile kosztowała promocja i obstuga programu. https://tvn24bis.pl/z-kraju,74/koszty-obslugi-i-promocji-programu-rodzina500-plus-mrpips,815908.html.

Kubicka-Żach, K. (2019, June 20). Urzędy moga polec na 500 plus. https://www.prawo.pl/samorzad/ obsluga-500-plus-w-gminach-koszty,433967.html.

Magda, I., \& Brzeziński, I. (2019). Rodzina 500+ ocena programu i propozycje zmian. https://ibs.org. pl/app/uploads/2019/05/Raport_500plus.pdf.

Malinowski, L. (2010). Od filantropii do pomocy społecznej. Praca socjalna, 2.

Ministry of Family and Social Policy. (2019). Projekt ustawy o zmianie ustawy o pomocy państwa 
w wychowaniu dzieci.https://www.gov.pl/documents/1048151/1060973/OSR500plus.pdf/6b0b8c6621c0-e867-509f-ddf7bdb4380a.

MM. (2019 January 2). 500 plus poprawił aktywność zawodową? Tak twierdzi GUS. https://www. forbes.pl/gospodarka/program-500-plus-a-aktywnosc-zawodowa-polakow-badania-gus/0rqt57r.

MP. (2019). Rodzina 500 plus po zmianach. Minister podaje nowe dane. https://tvn24bis.pl/z-kraju,74/ rodzina-500-plus-minister-rodziny-i-pracy-podaje-nowe-dane,978228.html.

MPIPS. (2019). “Rodzina 500+” - najnowszy raport. http://www.mpips.gov.pl/aktualnosci-wszystkie/ rodzina-500-plus/art,10147,rodzina-500-najnowszy-raport.html.

MPIPS. (2020, January 15). Najważniejsze zmiany w programie rodzina 500 plus. https://www.gov.pl/ web/rodzina/najwazniejsze-zmiany-w-programie-rodzina-500.

MW-G. (2020, September 4). "Koniec programów typu 500 plus i pieniędzy do ręki? Ministerstwo rozwoju zapowiada teraz zmiany, Retrieved from: https://pomorska.pl/koniec-programow-typu-500-plus-ipieniedzy-do-reki-ministerstwo-rozwoju-zapowiada-teraz-zmiany-8032020-r/ar/c1-14633397.

NIK. (2019). Ponad 67 mld zł trafiło do rodzin. https://www.nik.gov.pl/aktualnosci/ponad-67-mld-zltrafilo-do-rodzin.html.

Podgórska-Rykała, J., Zasuń, A. (2018). Prawne instrumenty polityki rodzinnej na przykładzie świadczenia wychowawczego wprowadzonego w związku z rządowym programem „Rodzina 500+” w gminie wiejskiej Lelów. Roczniki administracji i prawa, 18(1), 89-105.

PWC. (2016). Ulgi podatkowe i świadczenia rodzinne w UE. https://www.pwc.pl/pl/pdf/ulgipodatkowe-2017.pdf.

Rafalska, E. (2016). Wystąpienie Elżbiety Rafalskiej, Minister Rodziny, Pracy i Polityki Społecznej podczas pierwszego czytania rzadowego projektu ustawy o pomocy państwa w wychowywaniu dzieci w dniu 9 lutego 2016 r. Ministerstwo Rodziny i Polityki Społecznej. https://www.mpips.gov. pl/wsparcie-dla-rodzin-z-dziecmi/rodzina-500-plus/dokumenty-i-opracowania/wystapienie-elzbietyrafalskiej-minister-rodziny-pracy-i-polityki-spolecznej-podczas-pierwszego-czytania-rzadowegoprojektu-ustawy-o-pomocy-panstwa-w-wychowywaniu-dzieci-/.

Rudke, M. (2017, August 10). Na co Polacy wydaja 500 Plus. https://www.parkiet.com/Gospodarka---Kraj/308109893-Na-co-Polacy-wydaja-500-Plus.html.

Szarfenberg, R. (2017). Wpływ świadczenia wychowawczego (500+) na ubóstwo ogółem i ubóstwo dzieci na podstawie mikrosymulacji. http://rszarf.ips.uw.edu.pl/pdf/wplyw500+.pdf.

Szymański, D. (2020, January 29). Alarmujące dane GUS. Polska demografia ma się najgorzej od II wojny światowej. Business Insider. https://businessinsider.com.pl/finanse/makroekonomia/danedemograficzne-w-polsce-za-2019-r-gus-liczba-urodzen-i-zgonow/n0c74x3. 